\title{
Religious Radicalism, Global Terrorism and Islamic Challenges in Contemporary Indonesia
}

\author{
Choirul Mahfud, Niken Prasetyawati, Wahyuddin, Zainul Muhibbin, Dyah Satya Yoga Agustin \\ Institut Teknologi Sepuluh Nopember (ITS) Surabaya. \\ choirul.mahfud@its.ac.id
}

\author{
Heni Sukmawati \\ Universitas Siliwangi, Tasikmalaya. \\ henisukmawati@unsil.ac.id
}

Diterima: 02 Februari 2018

Direview: 29 Juni 2018

Diterbitkan: 27 Juli 2018

Hak Cipta @ 2018 oleh Penulis (dkk) dan Jurnal Sosial Humaniora (JSH)

*This work is licensed under the Creative

Commons Attribution International License (CC BY 4.0).

http://creativecommons.org/licenses/by/4.0/
Subject Areas: phenomenon, religion

\begin{abstract}
Discussing the radicalism of religion and global terrorism is a global challenge that is now a worldwide concern, including for the Islamic community in Indonesia. Research in this paper with an analytical descriptive approach using the documentative method. The general purpose of this research is to understand the root causes of terrorism and religious radicalism in Indonesia? What is the solution of Islam to overcome the problem of religious radicalism and global terrorism? The results of this research show: first, the historical roots of global terrorism and religious radicalism is a very complex portrait of social, political, and economic history. Also, the complexity of local, regional and global problems are interconnected with one another. Second, the Islamic solution to overcome this problem with the Islamic approach to peace for all (rahmatan lil alamin) which prioritizes the path of dialogue and world peace.
\end{abstract}

Keywords: Religious Radicalism; Global Terrorism; and Islam Rahmatan Lil Alamin.

\section{Introduction}

Post-tragedy $9 / 11$ until now, the talk about global terrorism continues to warm and attract the attention of many academics of social science humanities in various countries, including in Indonesia. Especially after the events of suicide in various regions of the world, not least in Indonesia. Recently, the testimony of KH Ma'ruf Amin, as chairman of the MUI Fatwa commission, whether the root of terrorism is suspected by religious fundamentalism and misinterpretation of jihad.

The phenomenon of religious radicalism and religious fundamentalism is becoming a bad phenomenon in the world (Amstrong, 1991; Azra, 2002). Here, many critics and problems for strengthening the role of Muslim societies, including in Indonesia (Abdurrahman, 2003; Ali, 2016; Baasyir, 2007). Unfortunately, the fundamentalism phenomenon itself is destructive, not constructive. Robert N. Bellah, an American sociologist, calling the above phenomenon a scripturalist phenomenon. Furthermore, Bellah argues that the tendency of this scripturalist group to see the Qur'an and Sunnah (read: scriptural text) as a perfect entity, and sacred. Those who act like that have made them fundamentalists. 
In the book on "The Challenge of Fundamentalism: The Politics of Islam and the Disorder of the New World", Bassam Tibi explains the problem of religious radicalism and fundamentalism is one of the problems in global world politics (Tibi, 1998; Casanova, 1994; Anwar, 2005). Tibbi argues that these fundamentalists perceive the West as failing in organizing and managing the world's map of progress and justice. Therefore, it needs to be appreciated for the new system. Unfortunately, all this is also limited to discourse and rhetoric. Many are pessimistic they are also successful in making efforts to create a new systemic and comprehensive order in social, economic, political, and other aspects. In contrast to Tibi and Bellah, Bruce B. Lawrence (1989) describes the symptoms of fundamentalism as an antimodernity phenomenon. In his book on "Defenders of God", he explains religious fundamentalism vis a vis modernity. Lawrence sees the unaffected fundamentalism of religious phenomena, but in its development, today fundamentalism is an ideological phenomenon. Fundamentalists do not seem to act radically and extremely in the name of God (Lawrence, 1989; Clarke, 2006; Gunawan, 2005; Brokers, 2003).

In revealing the phenomenon of religious fundamentalism and terrorism, Lawrence offers two approaches to context and counter-text. This Contextual Approach is meant to explain two main elements, namely: modernity and modernism. The two parts were used by Lawrence to determine the era of high-tech, which is, in Francis Fukuyama's term, the triumph of global capitalism. And the approach of counter-text to test responses and religious reactions to modernity and modernism. The phenomenon of fundamentalism is quite thick as the flourishing of violence and religious-clad extremism. There is ambiguity here. On the one hand, the fundamentalists and the radicals live in the environment of modernity in the form of modern technology. But on the other hand, they campaigned against the anti-modernism as an ideological movement against modernization (Hasan, 2016; Hasan, 2008; Clarke, 2006).

In this context, this paper would like to see more clearly about the problem of religious radicalism, global terrorism and the challenge of Islam in Indonesia in particular and the world community in general. Hopefully, there is a good understanding in looking at the situation of global terrorism that is under local conditions in Indonesia.

\section{Research Methods}

This research is a qualitative descriptive research that aims to describe and interpret systematically about the facts, and the relationship between phenomena investigated. This study uses qualitative methods to understand the various symptoms as being interconnected with each other in functional relationships and is a unity. In addition, the phenomenological approach is used to reinforce the meaning of the event and its relation in the context of a particular situation. With this approach, this research has the flexibility in such a way to look at the issues that become the focus of attention, so that the truth of information obtained can be as much as possible in accordance with the natural reality of the object of research. Data collection techniques used are documentation and other relevant sources. Moreover, qualitative research here needs to follow the flow of interactive model analysis, ie data collection, data presentation, data reduction, and verification (read Miles and Huberman). In its 
application, the data in this study were obtained, then presented, reduced, and verified.

\section{Research Results and Discussion}

In the last five years, the problems of radicalism, violence, extremism, intolerance and global terrorism continue to attract public attention. Even ahead of the upcoming election of governor and the presidential election in Indonesia. It is predicted that this issue includes crucial topics as well as homework that need to be thought of the solution early on by all people in Indonesia (Anwar, 2005; Turmudi, 2004; Friedman, 1994; Hefner, 2001).

It is necessary to appreciate the strategic steps taken by media in Indonesia who contribute to sharing the publication, information, and socialization to the public. Also efforts the Indonesian government through various ministries to synergize for the creation of state security. Also the role of universities in Indonesia which some time ago held a nationality action in Bali which was attended by President Jokowi. As we know that the issue of religious radicalism, global extremism and terrorism is not really a new problem at all. However, the phenomenon is now quite worrying and needs to be considered by all parties. President Jokowi asked the leaders of universities in Indonesia to anticipate the danger of anti-Pancasila movement and negative radicalism that also spread among students in this country (Held, 2004; Kersten, 2017; Latif, 2005).

The facts and data from a number of survey agencies also showed less encouraging results. According to Saiful Mujani Research and Consulting (SMRC) survey, the seeds of radicalism among Indonesian adolescents (students) are alarming. Based on the results of the survey, as many as 6.12 percents agreed that the bombing case Amrozi cs a few years ago is a religious command. Then, as many as 40.82 respondents answered "willing", and 8.16 percent of respondents answered "very willing" to attack people or groups who are considered insulting Islam. Respondents taken in the survey were mostly high school students and university students (Pepinsky, 2018; Mahbubani, 2005; Shihab, 1999).

The same report is also revealed in the Wahid Foundation survey results. It was reported that there were 7.7 percent of respondents willing to take radical action if there was a chance. Director of the Wahid Institute, Yenny Wahid, said many national survey institutions have conducted surveys and research related to religious radicalism. Based on the results of the survey, radical understanding in Indonesia is increasing. No wonder, if now many people are concerned about the increase in cases of intolerance and radicalism in Indonesia rather than the issues on peace and multiculturalism (Mahfud, 2016; Parekh, 2000; Woodward, 2004; Kivisto, 2002).

According to Yenni, the characteristics of radical groups in Indonesia are generally young and male. Yenni said that they consume a lot of religious information that contains suspicion and hatred. In addition, they also understand the religious teachings about jihad material or related to war verses than peace verses. Different but similarly, the National Agency for Combating Terrorism (BNPT) also reported the survey results related to radicalism. According to BNPT data, as many as 39 percents of students in 15 provinces in Indonesia who are respondents from surveys conducted indications are interested in radical understanding. The results of this survey reinforce the notion that the younger generation is the target of spreading radicalism and vulnerable campus to be the place of its spread. For 
that need to be anticipated early in order not to continue on terrorism.

Based on all data from the results of the above survey shows that the problem of radicalism is not a matter of trivial. Indeed, the reported figures are probably small. However, it remains to be realized together as a threat that should be wary of us all, especially for the world of school and higher education in the country. The reason, it is not impossible the number of the problem is many that can ultimately disturb the stability of security and life of the nation and state. When analyzed more carefully, many factors why radicalism, terrorism and extremism increase or weaken. In here, there are at least two main factors that need to be understood from the phenomenon of negative radicalism, namely: the pull factor and the push factor.

First, there is a pull from outside the actor or the victim in the practice of action toward radicalism and extremism. During this time, in addition to the influence of teachers who have the idea of radicalism/ extremism, the spread of radicalism also occurs due to the swift flow of information circulating in social media and internet that need to be supervised. Primarily understand the hatred and suspicion that freely circulate through WhatsApp, Line, Twitter, Facebook, Instagram, Youtube and other social media. Of course, it can all happen in the absence of an information filter, so it is out of control. Secondly, there is an inner impulse that has a bad attitude and character. This internal thrust, of course, needs to be understood as a driving/ push factor in taking actions toward radical or negative extremes that harm the other side and need good character guidance and education.

In this context, the solution of these two problem factors can be anticipated by a systemic and strategic approach to dialogue and education. Professor Syamsul Arifin in the book "Contemporary Islamic Studies; Flow of Radicalism in Indonesia", noting the need to optimize the role of educational institutions, including universities in preventing and offering alternative solutions to the negative radicalism movement through dialogue and education in the Indonesian campus. In essence, the early prevention of negative radicalism can be done by reinforcing creative, innovative, productive and cooperative educative activities based on four pillars of nationality, namely Pancasila, 1945 Constitution, NKRI and Bhinneka Tunggal Ika.

This is in line with the expectation of the Minister of Research, Technology and Higher Education, Mohamad Nasir who reminded that the university leaders are expected to play a role in fighting or preventing the growing of radicalism. In essence, radicalism needs to be denied by activating campus activity based on Pancasila education and four other pillars of nationality.

In this context, all universities have much homework. As mandated by Law no. 12/ 2012 on Higher Education affirmed that higher education as part of the national education system has a strategic role in the intellectual life of the nation and advancing science and technology by observing and applying the value of humanities as well as the sustainable culture and empowerment of the Indonesian nation. In order to counteract the ideology of radicalism in the campus, nowadays it should involve all lecturers and university lecture activities on campus based on four pillars of nationality. In this activity, new students and old students can be given national training in the hope of having a sense of responsibility as a good citizen (Kivisto, 2002; Mahfud, 2016). 
The use of good relationships between students with senior-junior students, alumni, student parent organizations as a means of preventing terrorism is an alternative choice. When the harmony and national solidarity among all elements of the nation continue to be built, then the idea of radicalism can be prevented to spread in society.

\section{Understanding the Roots of Terrorism}

AP Schmid and AJ Jongman (1988) define terrorism as an attempt to create anxiety with repeatedly negative attempts of violence. When observed that threats, violence, and suicide bombing are terrorist communication media in order to manipulate the main target (audience), resulting in the situation of public safety uncertainty. After that, in the end, the distrust of the authority of the ruler increases. A study has concluded that terrorism in Indonesia is closely related to the failure state or a country that failed to prosper its people fairly (Bergen, 2001; Daniel, 1993; Hendropriyono, 2009). Frustrated poor people, especially in rural farms, are very easily brainwashed by them to become terrorists or voluntarily enlist as suicide bomber suicides, in order to achieve group political goals-a certain group (Mubarak, 2007).

Today, with increasingly difficult living conditions due to multidimensional crises and natural disasters, it is predicted that these conditions will not get worse than before. Apparently, we do have problems in the country related to nation-building that has not been done until now. Evidently, the existing legal instruments (including both the apparatus and the criminal offenses) are often incapable of ensnaring criminals, including the terrorist group. We have often seen that those arrested and accused as terrorists are ultimately punished only mildly for administrative violations such as identity fraud. Terrorists everywhere can never be known exactly when and where they will attack, and do not care about the civilians who will become victims. This is clearly different from the officers who now have to work in the corridors of the law, with the principle of presumption of innocence (Schmid, 1994; Hefner, 2001; Friedman, 1994;).

The terrorists take advantage of administrative flaws in the midst of our society. Easily obtaining an ID card (KTP), passport or any document with a fake identity is the easiest gap and it is easily misused. We encourage the government to be more cautious, pro-active and crack down on the perpetrators of crime, particularly the perpetrators of a bomb in this country. The perpetrators of the bombing, whoever the person is and whatever the motive, are the real terrorist. They have terrorized and scared the innocent people. Therefore, we affirm that they are very barbaric, enemies of humanity and need to be on the same opponent.

The impact of tragedy bombs in some places can worsen the condition of the nation that was hit by the crisis. Minimal will hamper the flow of foreign investment and cause foreign tourists to fear to come to our country. In addition, Indonesia will be labeled as a hotbed of terrorists. At least we, especially the government and the security forces, are considered incompetent to combat terrorists. Worse than that, if there is slander or accusation addressed to Muslims (Turmudi, 2004).

When slander or accusation happens, we are worried that the friction and conflict between religious people will quickly flare up. The very bad economic conditions have now made our society very sensitive. The allegations and slanders, if they occur, will also disrupt the Muslims' worship in performing 
their worship. Especially in a few months before this, some events have also been used by certain parties to harass inter-religious harmony in this country. For example, the Ahmadiyah case, the fatwa of the Indonesian Ulama Council, the closure of a number of unlicensed churches in West Java, and so on.

Therefore, we remind everyone, especially the government, security apparatus, religious and community leaders, and political elites, not to be reckless in attributing bombing events with religious or other sensitive groups. All religions certainly do not teach or command acts of terror, killing, hurting, and so on. All religions, especially Islam-according to the meaning and origin of the word-always enjoin the people to create peace on earth.

\section{The Paradox of Religion and Jihad}

The commitment of nonviolence, peace, harmony, and prosperity is the noble goal of human life on earth. In the case of suicide bombings, we may still wonder why they are willing to commit suicide, sacrifice their lives, cut off the affections of their parents, their wives, children, and families? Behind it all, there must be very sublime ideas that they believe and strive for.

This terrorist group has actually been indoctrinated by the idea of taking a shortcut against modernization and civilization through violence and suicide bombing. Heidegger in his book "Discourse on Thinking", reminded that sometimes someone is having problems cannot think well (Heidegger, 1966). Confused about what to think about. As a result, one thinks short. Not long. In these circumstances, one can do what he can, even bad behavior to commit suicide. In addition to dwarf thinking, they interpret the scriptures according to their interests as a defense in carrying out the mission of destroying the order of life. Unfortunately again, borrowing the term Syafii Ma'arif, they are young men who dare to die but do not dare to live (Purnomo, 2009).

In this context, the slogan, "the spirit of courage to live, not dare to die" we think it should be contemplated together. The motto is considered important. The courage of terrorist groups to die, struggling to defend political interests by killing innocent people is actually a silly act. The struggle is not jihad, but terrorism and brutality by borrowing God's name or in the name of religion. The meaning of jihad should not necessarily be interpreted in bad, negative, destructive meanings and behaviors that harm innocent people. Nor is it the act that causes suffering for mankind and destroys civilization. Is not wise to kill a mouse by burning a house? Is it necessarily a dead mouse and cannot develop? What a real terrorist group does like the parable (Mubarak, 2007). Universal teachings encourage his people not to commit acts of violence and harm others. Recent terror acts are no more than the wishes of certain groups to disrupt the national security situation and hope to profit from the chaos. Regardless of its motives, terrorism is the enemy of all religious people and all nations anywhere and anytime (Azra, 2002).

In recent years, bombs have become the instruments of global terrorist groups in every action. Within minutes, three bombs went off in two places in Bali. As reported by mass media at that time, the first and second bombs exploded in Cafe Nyoman, Jimbaran. While the third bomb exploded and destroyed some areas around Raja's Bar and Restaurant in the complex of Kuta Town Square. Although a long time ago, the bombing incident left a problem for the people in Indonesia. Actually, what happened in Bali is just one of the bombing cases in 
the country. The Bali bombing tragedy can become a signifier and further insist that under no circumstances should the country be unaware. The state that never sleeps principle needs to be held and proven in safeguarding the security of bomb threats throughout the country, especially in Bali. Therefore, this Bali region, culturally, into a window of Indonesia. Apparently, the region that gets the praise of 'heaven for tourists' is now the main target of global terrorists (Mubarak, 2007).

The phenomenon of global terrorism becomes our common enemy, which must be resisted. Here, the role of the state is required to be extra active in safeguarding the security of the threat of global terrorism. In order not to happen again Bali bomb vol III and the perpetrators of crime cannot freely perform acts of terror. The Bali bomb that always took advantage of the momentum, was a very well planned and calculated crime. And, again, our country's security system is not able to deny it. The first Bali bomb indeed has been an example of police alertness in hunting down the perpetrators, but not on the root of problems. In fact, crime also has a loyal cadre.

Faced with such things, our intelligence officers really have to work extra hard. Because of the terrorist crime plan more neat and careful. While detection of the state proved increasingly lagging behind. We will all be relieved if the Bali bombers are also resolved. However, this nation will feel more secure if the savage people increasingly have no room to carry out the action. So as to realize a safe and peaceful society.

\section{Challenges to Strengthen Islam Rahmatan Lil Alamin}

Islam is a religion for all. Islam as a solution for the whole world known as Islam Rahmatan Lil 'Alamin. The question continues to be a topic of discussion among many Muslims in Indonesia and the world. Because, after the tragedy of September 11 , the Islamic community and the world is thrown with the issue of violence, religious radicalism and global terrorism that is contrary to the principles of peace, humanity, democracy and Human Rights (Mahfud, 2016; Hoesterey, 2015; Galtung, 2004).

The Islamic solution through the Islamic approach to Rahmatan Lil 'Alamin here is timely in response to contemporary Islamic issues and dynamics. The significance of this solution lies in the socio-political and religious background at the glocal level (global and local) while providing an alternative solution to the variety of issues concerning Islam that are often stigmatized as a religion of violence and global terrorism. Strengthening the Islamic education and the Islamic ethics is the very good solution for the problems (Muhibbin, 2008). Also empowering children in good life through culture and traditions of peace in the family is one way of educating people in the future (Suarmini, 2016).

The stigma has recently surfaced along with the rise of acts of terrorism and suicide bombing movements in various parts of the country and the world marked by the destruction of WTC twin buildings in the United States a few years ago. Regardless of right or wrong, the accused party who carried out the bombing action, incidentally, is Osama bin Laden from the Al-Qaeda Network. From that case, many Western observers have made the "instrument" justifying that Islam is a doctrine that spreads violence and terrorism. 
In fact, Samuel P Huntington in his book, "Who Are We?: The Challenges to America's National Identity," reaffirms for his thesis of the Clash of Civilizations, that the new enemy of the West is 'Islam, especially the militant, fundamental or radical (Huntington, 2004; Habermas, 1970; Shihab, 1999). Huntington's assertion is not without reason, as lately the tension between Islam and the West has strengthened again. Primarily, related to acts of terrorism and publishing cartoons of the Prophet Muhammad as well as other extremism issues. The question is whether this phenomenon can be called a new phenomenon of Islamic phobia? The answer may be and vice versa, no. As we now know, Islam and Muslims are often subjected to "iconization, symbolization", especially by the imaging by the Western mass media. The imagery eventually affects the attachment of negative "images" to the face of Islam (Jackson, 2004; Hoesterey, 2015). The face of Islam today is represented by figures like Osama bin Laden, and scenes of war, sword, violence, terrorism, to suicide bombings.

John L. Esposito, in an article describing the atmosphere of Islamic relations and the West again experience ups and downs, sometimes good than bad. When we look back, it is still fresh in our memory of some of the "mode" of Western imagery campaigns through the mass media, among them are: Suez crisis problems in 1955-1956, Arab-Israeli War in 1967, oil crisis problem 1973-1974 , The Iranian Revolution of 1978-1979, the 1989 Salman Rushdie case, the Algerian crisis of the 1990s, the Gulf War in 1991, and the hunting of Osama bin Laden terrorists in Afghanistan in 2002, the US Invasion of Iraq in 2003, the caricatures Prophet Muhammad in 2005 and later Iran's "peace" nuclear reactions in 2006 and recent events.
Bad imagery as mentioned above is obviously overdone, less basic and simplistic impressed. Islam is not substantially a doctrine that requires violence, suicide by any means or allows terrorism. Because terrorism is synonymous with terror, violence, extremism, and intimidation that often lead to negative consequences and incompatibility with universal Islamic values such as humanism, justice, democracy and human rights. At this crucial point, there are some critical questions that have not been completely resolved by all parties, is there a clear correlation between Islam and Terrorism? Is there any proof? Can any individual, group or religious movement of alleged masterminds of terrorism be a representation of a particular religion (Islam) and belief system, in both the domain of the teachings and the followers? The question needs to be asked and answered by all parties, especially the clergy (Azra, 2002).

In addition, the Muslims of the world should be behaving and speaking out loud but polite, that Islam is a doctrine that spreads peace and salvation while accompanied by concrete steps by participating in the creation of world peace (Fathurahman, 2016; Azra, 2002; Barker, 2004). Such statements of attitudes are important because the negative stigma is consciously or not harmful to Muslims throughout the world and exacerbates the image of Islam (Beilharz, 2005: Turmudi, 2004).

This alternative bid for world peace needs to be appreciated together in order to recover from the recent bad image of Islam. Presenting Islam in a fascinating framework full of grace for the whole world or rahmatan lil 'alamin, not rahmatan lil muslimin (specific Muslim) is important, so as not to get caught up in an exclusive, private, partial and primordial Islam. 
Discourse "Islam Rahmatan Lil 'Alamin" is not a new topic, but the subject is still actual because in the social level is not a doctrinal always find many operational hurdles that need to find a solution. Substantially, the topic of Islam as Rahmatan Lil 'Alamin includes several things: upholding the values of wisdom, 'adl (fair), tawassuth (moderate), tasamuh (tolerant), tawazun (balanced), i'tidal (consistent) and shura (dialogue). In addition, the ability of people to adopt the values of modern society without losing self-identity, such as multiculturalism, democracy, human rights, rationality, civil society, openness, and others. For it is not true of Imam Ali's statement that truth is something that is lost from a believer, then take that truth immediately from wherever it is (Turmudi, 2004; Shihab, 1999).

Along with the rapid flow of globalization, Islam is now faced with many challenges as well as opportunities. When Muslims can not seize roles and opportunities in the global public sphere and are not ready to face the new flows of globalization, it is likely to be retarded and retreated. Ziaudin Sardar, a Muslim thinker, recalls that Muslims are now colonized by the West. For Sardar, the most horrible practice of Western occupation of Islam lies more in the aspect of 'epistemological imperialism' (Ali, 2016; Azra, 2002).

In contrast to Sardar, Bassam Tibi in the book "The Threat of Fundamentalism, the Knows of Political Islam and the chaos of the New World" reveals that there is now a tugging between ashalah wa al-hadatsah (authenticity and modernity) in the Muslims. On the one hand, Islam wants to be modern and fears the loss of 'Islamic identity' on the other (Tibi, 2000). At this point, a question arises, is it possible to become a modern Muslim without
Western presence, whereas "modernity" is part of Western products?

The answer to this question depends on Muslims in the world. Here, Islam will be able to be more modern than the West, when Islam wants to offer a useful alternative to the world. With another language, Islam will be able to lead if able to spread the values rahmatan lil'alamin (Islam for all). In the context of global public space, the struggle for roles is no longer a strange and strange thing as much expressed by sociologists and communications such as Max Weber and Juergen Habermas.

The conflict and tension between religions and civilizations in the world, such as riots in Pattani Thailand, Poso, Palu, Palestine-Israel and others, should be resolved by taking the path of dialogue. But the dialogue must be dialogical. Dialogue is important because so far the path of dialogue than not dialogical is also unequal, balanced and fair. In addition to a dialogical dialogue, it is even more important to build a solidly realized world solidarity by continuing to maintain world peace that is based on a fair, peaceful and prosperous global ethic of life.

\section{Conclusion}

From the analysis that has been done as described above, there are some important conclusions from this research:

1. The root cause of global terrorism and religious radicalism in Indonesia is a very complex portrait of social, political, and economic history. Moreover, the complexity of local, regional and global problems is intertwined with one another.

2. Various problems of religious radicalism and global terrorism, Islam provides an alternative solution in overcoming the problem with Islamic approach on Islam for all (rahmatan lil alamin) 
that prioritize the path of dialogue and world peace.

3. Islam rahmatan lil alamin is a conception based on active and participative verbs to support the creation of advanced, fair, sovereign, peace and prosperous society.

\section{Recommendation}

In this paper, the authors as the researcher provide some suggestions or recommendations for the attention of all parties, in order to be more optimal in answering the problem of religious radicalism and global terrorism. First, starting with ourselves. Everyone is expected to be responsible for creating a peaceful and non-violent lifestyle and anticipating the problem of radicalism and terrorism. In this case, every Muslim is expected to be a problem solver rather than a problem maker. Minimally every individual would be part of the solution. Second, the Muslim community in Indonesia is expected to synergize in preventing the growing radicalism and global terrorism. Third, the government is expected to guarantee a just, prosperous and prosperous social life order. Fourth, all stakeholders of world peace are expected to always anticipate the problem of radicalism and global terrorism early on.

\section{Bibliografi}

Abdurrahman, Moeslim. (2003). Islam sebagai Kritik Sosial. Jakarta: Erlangga.

Ali, Muhamad. (2016). Islam and Colonialism: Becoming Modern in Indonesia and Malaya. Edinburgh: Edinburgh University Press

Amstrong, Karen. (1991). Holy War: The Crusades and Their Impact on Today's World. New York: Anchor Books.

Anwar, Dewi Fortuna. (2005). Violent Internal Conflict in Asia Pacific. Jakarta: Yayasan Obor dan LIPI.

Azra, Azyumardi. (2002). Konflik Baru AntarPeradaban: Globalisasi, Radikalisme \& Pluralitas. Jakarta: Raja Grafindo Persada.
Baasyir, Abu Umar. (2007). Teroris Melawan Teroris. Yogyakarta: Mawazin.

Barker, Chris. (2004). Cultural Studies: Teori dan Praktik. Yogyakarta: Kreasi Wacana.

Beilharz, Peter. (2005). Teori-Teori Sosial. Yogyakarta: Pustaka Pelajar.

Bergen, Peter L. (2001). Holy War, Inside the Secret World of Osama bin Laden, Inc. London: Weidenfeld \& Nicolson.

Brokers, Mathias. (2003). Konspirasi, Teori-Teori Konspirasi dan Rahasia 11-9. Jakarta: Ina Publikatama.

Casanova, Jose. (1994). Public Religions in the Modern World. Chicago: the University of Chicago Press.

Clarke, Peter. (2006). New Religions in Global Perspective. New York: Routledge.

Dahlan, Muhidin. (2000). Sosialisme Religius; Suatu Jalan Keempat?. Yogyakarta: Kreasi Wacana.

Daniel, Norman. (1993). Islam and the West: The Making of an Image. Oxford: Oneworld.

Fathurahman, Oman. (2016). Shattariyah Silsilah in Aceh, Java, and the Lanao Area of Mindanao. Tokyo: ILCAA-TUFS.

Friedman, Jonathan. (1994). Cultural Identity and Global Process. California: Sage Publications.

Galtung, Johan. (2004). Studi Perdamaian. Surabaya: Pustaka Eureka.

Gunawan, Jamil. (2005). Desentralisasi, Globalisasi dan Demokrasi Lokal. Jakarta: LP3ES.

Habermas, Jurgen. (1970). Toward a Rational Society. Boston: Beacon Press.

Hasan, Noorhaidi. (2008). Laskar Jihad: Islam, Militansi, dan Pencarian Identitas di Indonesia Pasca-Orde Baru. Jakarta: Pustaka LP3ES.

Hasan, Noorhaidi. (2016). Public Islam in Indonesia: Piety, Politics, and Identity. Amsterdam: Amsterdam University Press.

Hefner, Robert W. dan Patricia Horvatich. (2001). Islam di Era Negara-Bangsa. Yogyakarta: Tiara Wacana.

Held, David. (2004). Demokrasi dan Tantangan Global. Yogyakarta: Pustaka Pelajar.

Hendropriyono, A.M. (2009). Terorisme, Fundamentalis, Kristen, Yahudi, Islam. Jakarta: Buku Kompas.

Hoesterey, James Bourk. (2015). Rebranding Islam: Piety, Prosperity, and a Self-Help Guru. USA: Stanford University Press,

Jackson, Robert. (2004). Rethinking Religious Education and Plurality: Issues in Diversity and Pedagogy. New York: Routledge Falmer.

Kersten, Carool. (2017). A History of Islam in Indonesia. Edinburgh: Edinburgh University Press. 
Kivisto, Peter. (2002). Multiculturalism in a Global Society. USA: Blackwell Publishers.

Latif, Yudi. (2005). Intelegensia Muslim dan Kuasa. Bandung: Mizan.

Mahbubani, Kishore. (2005). Bisakah Orang Asia Berpikir?. Jakarta: Teraju.

Mahfud, Choirul. (2016). Pendidikan Multikultural. Yogyakarta: Pustaka Pelajar.

Mahfud, Choirul. (2014). The Role of Cheng Ho Mosque: The New Silk Road, Indonesia-China Relations in Islamic Cultural Identity. Journal of Indonesian Islam 8.1.

Mubarak, M. Zaki. (2007). Genealogi Islam Radikal di Indonesia: Gerakan, Pemikiran dan Prospek Demokrasi. Jakarta: Pustaka LP3ES Indonesia.

Muhibbin, Zainul. Korelasi Antara Kecenderungan Teologi Dengan Opini Etos Kerja, Jurnal Sosial Humaniora, Vol.1, No.2, November 2008, 128141.

Parekh, Bhikku. (2000). Rethinking Multiculturalism. New York: Palgrave.

Pepinsky, Thomas B. Liddle, R. William and Muzani, Saiful. (2018). Piety and Public Opinion: Understanding Indonesian Islam. USA: Oxford University Press.

Purnomo, Agung. (2009). Ideologi Kekerasan: Argumentasi Teologis-Sosial Radikalisme Islam. Yogyakarta: Pustaka Pelajar.

Schmid, Alex. (1994). Political Terrorism: A Reaserch Guide. USA: Trans Action Books.

Shihab, Alwi. (1999). Islam Inklusif. Bandung: Mizan.

Suarmini, Ni Wayan, Ni Gusti Made Rai, Marsudi, Karakter Anak Dalam Keluarga Sebagai Ketahanan Sosial Budaya Bangsa, Jurnal Sosial Humaniora, Vol 9 No.1, Juni 2016, 78-95.

Turmudi, Endang. (2004). Perselingkuhan Kiai dan Kekuasaan. Yogyakarta: LKIS.

Woodward, Mark R. (2004). Islam Jawa; Kesalehan Normatif VS Kebatinan. Yogyakarta: LKIS. 